\title{
The effectiveness of generating interactions between schemata and text (gist) strategy towards the students' writing skill in Indramayu
}

\author{
Indra Yoga Prawiro ${ }^{1}$, Siska Nurhasanah ${ }^{2}$ \\ 1,2English Education Departement, Wiralodra University, Indonesia \\ 1yogaprawiro@gmail.com, 2nurhasanahsiska280@gmail.com \\ *) correspondence: yogaprawiro@gmail.com
}

\begin{abstract}
Many students have difficulties in writing the text. Some of the problems in writing such as the difficulties in expressing their idea into the words, time consuming activities and the limited number of vocabularies. This study focused on the effectiveness of GIST (Generating Interaction between Schemata and Text) strategy in improving students' writing skill at the second grade of SMK Negeri 1 Sindang. The GIST is strategy for taking notes while the students are reading and writing good summaries. This strategy works on many levels, this allows students to put concept into their own words. This activity helps teachers and students to identify key concept. By using quasi-experimental method non-equivalent design, the instruments of this research were pre-test and post-test. The participants of the research were class XI TOI 1 and XI TOI 2 of first semester in SMK Negeri 1 Sindang. Each class consisted of 33 students. The statistical analysis showed the value of $\mathrm{T}_{\mathrm{obs}}$ was 2.23 while the value of $\mathrm{T}_{\text {table }}$ was 1.669 which means $\mathrm{T}_{\text {obs }}$ was higher than $\mathrm{T}_{\text {table }} 2.23>1.669$ ( $\left.\mathrm{T}_{\text {obs }}>\mathrm{T}_{\text {table}}\right)$. It means that the GIST strategy is effective in teaching and learning writing especially in report text.
\end{abstract}

Key words: GIST strategy; writing skill; report text

\section{INTRODUCTION}

In learning English, there are Four English Skills that should be mastered by the students, there are speaking, listening, reading and writing skill. Nunan (2003) defined that writing is the process of thinking to invent ideas, thinking about how to express into good writing and arraging the ideas into statement and paragraph clearly. Writing is one of language skill that are required by students in teaching learning process. There are several definitions given by linguists about writing. Informed by Flynn and Rhona (2006) writing is used by writers to translate their ideas into words on the page so they can communicate their ideas to other people. In addition, Brown (2001), demonstrates that written language is simply the graphic representation of spoken language, and that written performance is much like oral performance, the only difference lying in graphic instead of auditory signals. It means that writing is a way of communicating and sharing one's idea to other people through a written language.

In addition, Yule (2010) shows that writing as define as the symbolic representation of language through the use of graphic signs. It mean that writing is represntation of language through a text using sign or symbol. Informed by Graham (2016) improving students' writing skills helps them succed inside and outside the classroom. Effective writing is a vital component of students' literacy achivement. Based on the explanation above, the writers get the conclusion that writing is the way to show the communicating and sharing the ideas. And writing is representation of language through text or symbol. And also, writing is importance skill that the students must master it. 
In this study, the writers choose report text as a text to be learnt and improved by the students. According to Gerot and Wignell (1994) stated that report is a text which functions to describe the way things are, with references to a range of natural, manmade and social phenomenna in our environment. Report means a text which describe things in general. It's a little bit different from descriptive text which describe specific thing. To tell the facts of the things described, the writer usually uses simple present tense. Except, the things are extinct, simple past tense is used in report. Report text contains the class or subclass of the topic describe, and them followed by telling the shape, parts, behavior, etc in details.

However, the previous research showed some problems faced by students in writing. First, Utami, H., Raja, D., \& Nainggolan, F (2017) showed that the students often get difficulties to express their ideas into words or sentences. And then the second, Tristy (2010) showed that students felt boring and they less want to increase their ability on writing. The third, Purwasih (2018) indicated that lack of vocabularies is also a problem for students to write, particulary for the beginner writer. Then, the students try to avoid writing because it needs a long process to create a good writing and it is too complicated. In addition, it is Pirangelo and Giuliani (2006) stated that students in educational system feel that writing process takes a long time, so they are common to dislike or avoid writing activity.

To solve the problem above, the writers applied the Generating Interaction between Schemata and Text (GIST) strategy to help the students in writing. The acronym 'GIST' stands for Generating Interaction between Schemata and Text. The interaction is supposed to happen between the schemata, that is the past experiences and background knowledge of the learners and the text they will read. GIST is a strategy used for supporting reading comprehension, reading informational text, and summarization. Cunningham (in Herrel:2000) found that GIST can improve students' reading comprehension and summary writing. Since it is successful in increasing reading comprehension, in this research GIST was modified to improve students writing skill. It can facilitate students writing because in writing process students are required to generate interaction between schemata and text likewise in reading process.

Herrel (2000) says that GIST has some advantages. The GIST is especially helpful when students are required to read long texts containing a significant amount of new information. In addition it is also developed to help students learn to write organized. It assists readers as they organize their thoughts for class discussion, research, and writing. Moreover, he also mentions that implementing GIST in classroom can support comprehensible input for the students, give opportunities to increase verbal interaction, encourages active involvement, support contextualizing language, and reduces anxiety. In conclusion, GIST is beneficial for every students in classroom. It is not for English language learner only, but it had been implemented to science students too.

According to Brummitt and Yale (2007) students become better writers when they read extensively. Reading a variety of genres helps students learn text structures and language that they can then transfer to their own writing. In addition, reading provides students with prior knowledge that they can use in their stories. One of the primary reasons that students read is to learn. Especially while they are still in college, a major portion of what they know comes from the texts they read. Since writing is the act of transmitting knowledge in print, they must have information to share before they can write it. Therefore reading plays a major role in writing.

Generating Interaction between Schemata and Text (GIST) is summarizing strategy to help students pull out the most important information. According to Cunningham (1982), there are some explicitly teaching procedures that help the teacher to present GIST strategy as follows:

1. Choose an informational paragraph from a science, history, etc. textbook. Scan the text pulling out any key ideas from the text features. Read the text. (Pick a textbook piece that contains some trivia, as well as several ideas). Put the text on the overhead or board.

2. Continue reading and demonstrate picking out the who, what, when, where, why of the paragraph and related important information.

3. Demonstrate pulling together the above information into a $10 / 20$-word 'GIST' or summary. 
4. In pairs, guide students in completing a 'GIST' sheet. Support students in creating summaries until they can do them independently. The number of words in a 'GIST' summary can vary.

This teacher should observe and guide students with these summaries. These can be done individually or in small groups. Student can share their summaries with the whole class. Students should be given opportunities to practice and use the GIST summary strategy. Summarization can be tricky and on going practice that can help reinforce this skill.

Therefore, based on the background of the study above, the writers formulated the question as follows: "Is Generating Interaction between Schemata and Text (GIST) Strategy effective to improve students writing skill?”

\section{METHODS}

This research used the quasi-experimental design with non-equivalent control group, pre-test - posttest design. Informed by Creswell (2012) Quasi-experiments include assignment, but not random assignment of participant to groups. The writers used two classes in which one of them is experimental class and another is as controlled class. Experiment class is class which get treatment or being taught by using the GIST strategy and control class is taught by using conventional technique. The participants of the research were class XI TOI 1 and XI TOI 2 of first semester in SMK Negeri 1 Sindang. The class consisted of 33 students. In this research, the writers applied test as instrument to get data that support the research. Pre-test and post-test were conducted to get the data about the students' achivement in writing. Creswell (2012) informs that a pre-test provides a measure on some attribute or characteristic that you assess for participants in an experiment before they receive a treatment. A pre-test was used to know the students' capability before the writers gave treatment. The writers give the pre-test in the first meeting before the treatment applied. And for post-test, Cresswell (2012) argues that a post-test is a measure on some attribute or characteristic that is assessed for participant in an experiment after a treatment. After the last meeting of the treatment the post-test was administrated to the class. The purpose of post-test is almost the same with the pre-test, the difference is post-test given after the treatment.

\section{RESULTS AND DISCUSSION}

The result of the pre-test showed that there were many students got difficulties when they started writing. Most of them did not know what they would write about. They did not how to write report text and also had no understand what content would they write. Then, did not know about generic structure of report text. As Gerot and Wignell (1994: 196-197) explained that the organization of report text is general classification and description, and sometimes is has a conclusion that summarizes the information and signals the end of the report.

In the second meeting at the experimental class, the writers explained about a report text and the GIST strategy. By using this strategy, the students were more active (in the class, the students who has lower ability can ask and discuss their weakness to the students who has higher ability in learning English and also with the teachers who taught the material), and try to write what they have read or summarize. While in the control class, the writers explain about report text conventionally or without the GIST strategy.

In the last meeting, the writers gave the post-test in experimental class and control class. The purpose of post-test was to identify the students achievement after the treatment. It was used to know students' writing skill after learning report text through the GIST strategy. The writers distribute the post-test and explained some the unique building in Indramayu.

The result of the study showed that the pre-test average in experimental class was 58,24 , with the lowest score was 44 and the highest score was 82 . The pre-test average in control class was 57,51 , with the lowest score was 47 and the highest score was 87 . The post-test average in experimental class was 77,78 with the lowest score was 50 and the highest score was 92 . The post-test average in control class was 72, with the lowest score was 48 and the highest score was 87. 
The average of post-test score in both experiment class and control class are different: the average of the post-test score in experimental class was higher than control class. Referring to statistical analysis, the value of $T_{\text {obs }}$ was 2,23 while the value of $T_{\text {table }}$ is 1.66 . then, the value $T_{\text {obs }}$ was higher than $\mathrm{T}_{\text {table }}$ and Alternative Hypothesis $(\mathrm{Ha}$ ) was accepted while Null Hypothesis (Ho) was rejected. So, the GIST strategy is effective to improve students writing skill especially in report text.

Referring to the pre-test in control class, the student $\mathrm{S}$ only got 53 . It was the middle score in pre-test. The students got that score because there were some mistakes in language use and mechanics. Based on the pre-test the students $\mathrm{S}$ only got 17 point in content, because in her content was limited and did not show more knowledge of subject. It can be seen in her result text that just wrote 1 sentence 1 paragraph, that is "The center where young people from Indramayu hang out to families here, provides a variety of foods and drinks that vary around the area." And the organization got 14 point, because she loosely organized, that is no relation to the paragraph, there is no cohension (not showing a clear relationship between them), she did not organize the text properly, unsystematically, and there was no relation between one sentence to another it can be seen on the text above, but she still tried to explain her main idea from the theme or title that she used. Then, his vocabularies and frequent errors of word from choice usage. Then, she got 11 point in language use because when she tried to show her idea her contractions were still so simple, its mean that, she still wrote just 1 sentence, that was not thoroughly. And the last, she got 2 point in mecanics, because his punctuantion and errors or spelling "family" to be "families" and she did not pay attention to the capitalization, she wrote "provides a variety $o F$ Foods and drinks". However, in his post-test $\mathrm{S}$ got a score og 86 a lot of improvement from her pretest. The post-test S got 27 in content, because she could show the knowledge of subject and substansively, its mean that she knew knowledge about writing a report text, it can be seen from the post-test that is consist of three paragraph, for the first paragraph contain of General Classification. Beside that, she wrote "Indramayu islamic center mosque which is touted as the grandest and largest mosque, ... is located at simpang lima pekandangan..." And in second paragraph contain of Description. She wrote "The mosque bulding is decorated with 3 domes. The largest dome is located in the middle of the building and flanked by two smaller domes, located on either side.". In her vocabulary got 17 point, because she could put a suitable vocabulary in her written. And in her language use got significant improvement 20 point, because she tried to make good contruction. Then, in her mecanics got 4 point, because she occasionally error. And the last, organization she got 18 point, because her ideas clearly and fluent expression.

Reffering to the pre-test in experiment class, the writer found KA got score of 63 and her score in post-test was 87 . The student KA showed significant improvement from pre-test to post-test, and she also got high gain of 24 . In pre-test she made some mistakes including limited vocabulary, language use and mechanics such as punctuation and capitalization. She wrote "Tirtamaya Beach is a beach tourism park located in the City of indramayu." In that text, she did not pay attention to the capitalization. And the next sentence, she wrote "This beach is a mainstay destination that is often a lot of visitors when the holidays arrive." Besides that there were some mistakes from that sentence, such as "arrived" to be "arrive". In short she did not know how to write report text. She did not even write in paraghraps but rather simple sentence into points. In post-test KA got a score of 87 a huge improvement from her score of 63 from pre-test.

Based on pre-test and post-test result, the writers found the students who obtained the highest score was DAS, who had a pre-test score of 72 and post-test she gets score 92 . The report text that she wrote in pre-test and post-test were both good, and she was given the highest score because some aspects of her text demonstrated considerable skill, such as content of text, good vocabulary, and structured organization of her text. Even though she made some mistakes, nevertheless she showed improvement in writing report text under the influence of the GIST strategy. From pre-test to posttest, her gained 20 point.

The data showed that the students got a low score because the students did not know about report writing clearly, how to write report text with a generic structure, they lacked vocabulary, lacked ideas and lack of language use in good paraghraph skills. However, when the writers gave the treatment, their writing skill of report text were influenced positively. So, the data has shown the 
students are good in writing report text, even though there are some students does not improve in their writing skill. The teacher needs some method to improve students' potential in writing skill.

The average of post-test in both experiment class and control class are different: the average of the post-test score in experimental class was higher than control class. Referring to statistical analysis, the value of $T_{\text {obs }}$ was 2.230 while the value of table is 1669 . Then, the value $T_{\text {obs }}$ was higher than $T_{\text {table }}$ and Alternative Hypothesis (Ha) was accepted while Null Hypothesis (Ho) was rejected. So, the GIST strategy effective in teaching writing skill especially in report text.

From the discussion above, it can be concluded that there were some improvement in pre-test and post-test. The results can be seen from the table as follows:

TABLE 1. The Test Result

\begin{tabular}{|c|c|c|c|}
\hline Class & Instrument & Criteria & Score \\
\hline \multirow{6}{*}{$\begin{array}{l}\text { Experiment Class } \\
\text { (XI TOI 1) }\end{array}$} & \multirow{3}{*}{ Pre-Test } & High Score & 82 \\
\hline & & Lowest Score & 44 \\
\hline & & Mean & 58,24 \\
\hline & \multirow{3}{*}{ Post-Test } & High Score & 92 \\
\hline & & Lowest Score & 50 \\
\hline & & Mean & 77,78 \\
\hline \multirow{6}{*}{$\begin{array}{l}\text { Control Class } \\
\text { (XI TOI 2) }\end{array}$} & \multirow{3}{*}{ Pre-Test } & High Score & 87 \\
\hline & & Lowest Score & 47 \\
\hline & & Mean & 57,51 \\
\hline & \multirow{3}{*}{ Post-Test } & High Score & 87 \\
\hline & & Lowest Score & 48 \\
\hline & & Mean & 72 \\
\hline
\end{tabular}

The statistical calculation showed that the pre-test average in experimental class was 58,24 , with the lowest score was 44 , and the highest score was 82 . The pre-test average in control class was 57,51 , with the lowest score was 47 and the highest score was 87 . The post-test average in experimental class was 77,78 , with the lowest score was 50 , and the highest score was 92 . The post-test average in control class was 72, with the lowest score was 48 and the highest score was 87 . From the table, it is clearly seen the experimental class scored higher than control class, this is because the experimental class had been treated with GIST strategy while control class had not. Therefore, the writers concluded that the GIST strategy was effective to improve students writing skill especially in report text.

\section{CONCLUSION}

Through process analyzed data of pre-test and post-test score from control class and experiment class by Statistical Package for the Social Science (SPSS), the writers can measure whether any significant differences or not both of two classes. After analyzed the data from pre-test and post-test. The writers knew that the experimental class who taught by the GIST strategy showed significant achievement from pre-test to post-test, in the other hand the class who taugh by conventional strategy not showed significant differences from pre-test to post-test. It also showed that the GIST strategy is effective in teaching and learning writing skill especially in report text.

Based on the data that have been collected and analyzed, it can be inferred that the GIST strategy is effective to use in teaching writing skill especially in report text. It can be seen from the mean of gained score of experimental class, which is taught by the GIST strategy, and from controlled class, which is taught without the GIST strategy. The mean of gained score from experimental class is higher 
The effectiveness of generating interactions between schemata and text (gist) strategy towards the students' writing skill in Indramayu

than that of the controlled class. It is also proved from the result of T-test which showed that the value of to (2.230) is higher than the value og T-t from the $\mathrm{df}(64)$ in significance degree $5 \%(1,66)$ $2.23>1$,68. It indicates that the Null Hypothesis (Ho) is rejected and the Alternative Hypothesis ( $\mathrm{Ha})$ is accepted. Therefore, it can be concluded that the GIST strategy is effective to apply in teaching and learning writing skill especially in report text.

\section{REFERENCES}

Brown, H. D. (2001). Teaching by Principles. London: Longman.

Brummitt, J., \& Yale, C. (2007). The Relationship between Reading and Writing. Retrieved from http:/ /www.k12reader.com

Creswell, J. (2012). Educational Research. Boston: Pearson.

Cunningham, J. (1982). Generating Interaction between Schemata and Text. In national Behavior Support Services.

Flynn, N., \& Rhona, S. (2006). The Learning and Teaching of Reading and Writing. West Sussex: Whurr Publishers Limited.

Gerot, L., \& Wignell, P. (1994). Making Sense of Functional Grammar. Sydney: AEE (Antipodean Education Enterprises).

Graham, S. (2016). Teaching Secondary Students to Write Effectively. Washington, DC: IES.

Herrel, A. (2000). Fifty Strategies for Teaching English Language Learners. New Jersey: Prentice Hall, Inc.

Nunan, D. (2003). Practical English Language Teaching New York. The McGraw Hill Companies, Inc.

Pierangelo, R., \& Giuliani, G. (2006). Assesment in Special Education: a Practical Approach (2rd ed). Boston: Allyn and Bacon.

Purwasih, D. (2018). The use of Personal Letter Material to Improve Students' Writing Skill in Recount Text. Salatiga: IAIN Salatiga.

Tristy, R. T. (2010). Improving Students' Skill in Writing Report Text with All About Animal VCD. Semarang: Perpustakaan UNNES.

Utami, H., Raja, D., \& Nainggolan, F. (2017). The Effectiveness of Teaching Recount Text Through Clustering Technique. Bandar Lampung: University Lampung.

Yule, G. (2010). The Study of Language. Cambridge: Cambridge University Press. 